DOI https://doi.org/10.30525/978-9934-26-004-9-50

\title{
РОБОЧІ ЗОШИТИ-АЛЬБОМИ МИКОЛИ НЕВІДОМСЬКОГО: СТОРІНКИ ТВОРЧОГО ЖИТТЯ ХУДОЖНИКА ТЕАТРУ
}

\author{
Майстренко-Вакуленко Ю. В. \\ кандидат мистеитвознавства, доцент, \\ завідувач кафедри сиенографії та екранних мистецтв \\ Національної академії образотворчого мистецтвв і архітектури \\ м. Київ, Украӥна
}

Українська сценографія першої третини XX століття $є$ однією 3 найцікавіших мистецьких царин. Театральні колективи створювались $\mathrm{i}$ розпадались, реорганізовувались, гастролювали різними областями України, створюючи загальне культурно-мистецьке середовище, із яким була пов'язана доля ряду українських художників. Творчість багатьох із них $\mathrm{i}$ досі залишається малодослідженою, зокрема й образотворча спадщина українського сценографа Миколи Невідомського. Біографічні відомості про митця є досить скупими, уривчастими і розрізненими. Перші згадки про творчий шлях Невідомського відносяться до першої половини 1920-х років, коли молодий художник створював оформлення багатьох вистав для Першого державного драматичного театру імені Т. Шевченка [9, с. 107]. Він, зокрема, здійснив сценографію до вистав «97» М. Куліша (1925, режисер М. Тінський) [2, с. 162], «Мандат» М. Ердмана (1926, режисер Л. Кліщеєв) [2, с. 165] та «Віринея» Л. Сейфулліни (1926, режисер М. Сергєєв) [9, с. 214]. Як і більшість тогочасних українських сценографів, Микола Невідомський стояв «на конструктивістичних позиціях» [8, с. 3155-3157], при цьому митець був не лише автором цікавих сценографічних рішень, але й керівником та засновником ряду театрів.

У журналі «Сільський театр» за 1929 рік було опубліковано уривок 3 листа М. Невідомського до редакції, який містить цікаві відомості про роботу митця у якості організатора та керівника театральних колективів. Невідомський описує усі складності, особливо фінансові, тогочасної роботи, а також плани по організації театру малих форм: «В 1926 році пощастило зібрати акторський склад до 60 осіб, режисерів Юхименка, Бережного, згоду дав Кліщеєв. Утворили театр ім. Котляревського (...) Розпався театр ім. Котляревського, 3 його рештків утворився Полтавський РСТ. Менше року жив цей РСТ, а далі утік...» [7, с. 28]. На 
початку 1929 року Полтавська «окрполітосвіта спільно 3 посередробмисом доручила тов. Миколі Невідомському організувати новий пересувний театр» [7, с. 28]. Таким чином, зусиллями Невідомського було засновано Український пересувний театр сатири «Червоний перець». Протягом лише першого року роботи театр показав 243 вистави у 117 населених пунктах Полтавського, Лубенського, Харківського, Сумського, та Сталінського округів [9, с. 283].

У другій половині 1930-х років Микола Невідомський співпрацював із Черкаським пересувним робітничо-колгоспним драматичним театром, утвореним на базі третьої майстерні театру «Березіль» (здійснив сценографію до вистави «Назар Стодоля», 1939, режисер М. Попов) [6, с. 76]. Згідно атрибутації ескізів костюмів та декорацій художника 3 колекції Музею театрального, музичного та кіномистецтва України (МТМК), він також виконав для Черкаського театру оформлення до вистав «Марина» за твором Т. Шевченка «Наймичка» (1937) та «Глибоке коріння» за Д. Роу і А. Дюссо. В ці роки ім'я Невідомського пов'язане також із Київською кіностудією, де він працював як мультиплікатор [5, с. 154]. Після війни Микола Невідомський здійснив ще один варіант сценографії та костюмів до вистави «Глибоке коріння» (1946-47, за Д. Роy i А. Дюссо) на сцені Білоцерківського театру імені П. К. Саксаганського (фонди МТМК). Твори художника наступних років у музейних колекціях не збереглися; можливо, пролити світло на його подальшу долю вдасться шляхом вивчення листів, написаних М. Невідомським до Л. Тичини, дружини П. Тичини, протягом 1963-1974 років [11, с. 215].

Частина творчої спадщини Миколи Невідомського, яка збереглася у колекції МТМК, складається із ескізів сценографій та костюмів до різних вистав (1922-1947); натурних начерків та акварелей (перша половина 1920-х); дружніх шаржів на акторів (1922) та двох робочих зошитів (1924). Особливий інтерес для вивчення творчості Миколи Невідомського представляють саме робочі зошити художника, які не лише розкривають особливості ходу творчої думки, стилістичної спрямованості сценографічних рішень, але й дають можливість атрибутації здійснених Невідомським вистав.

Робочий альбом (Е 4783) Миколи Невідомського складається із 3 54 аркушів розміру $21,5 \times 34,2$ см, зібраних у два великі зшитки відповідно обгорткового та олександрійського паперу. Вугільні натурні начерки та зарисовки, портрети акторів у ролях, ескізи до вистав «Страшна помста» (в переробці письменника І. Галюна, режисер М. Тінський), «Лісова пісня» Л. Українки, «Наталка Полтавка» 
I. Котляревського, «Ревізор» М. Гоголя, «Пошились у дурні» М. Кропивницького виконані графітним олівцем, іноді у поєднанні 3 білилами, або вуглем та крейдою; у деяких аркушах використано акварель та гуаш.

На сторінках робочого блокноту (Е 4757), який складається 3 52 аркушів удвічі меншого розміру - 21х16 см - серед чисельних зарисовок інтер'єрів та пейзажів, міститься ряд ескізів сценічних декорацій та костюмів (деталей костюмів) до вистави «Палії» («Полум’ярі») за А. Луначарським, а також начерки артистів у ролях здійсненого спектаклю. Ескізи сценографії виконані Невідомським впевненою конструктивною лінією; увага художника зосереджена на структуруванні простору, виявленні його організаційних характеристик, що особливо прочитується у ескізах на 19, 23, 37, 47 та 48 сторінках. Співставлення інтер'єру та екстер'єру в одному аркуші (с. 23) посилює відчуття динаміки, одночасно і структуруючи, і ламаючи простір. Невідомський свідомо використовує відхилення ліній стін, стелі, труб та дахів від правильних вертикалей та горизонталей, насичуючи таким чином простір потенційною енергією руху. Цей художній хід узгоджується із міркуваннями авангардиста О. Богомазова, викладеними в трактаті «Живопис та елементи» щодо «виявлення живописного достоїнства даної лінії у зв'язку із тим середовищем, у яке ця лінія попадає» [1, с. 49].

Микола Невідомський виконав ряд зарисовок артистів в ролях персонажів цієї вистави, зокрема, Н. Дробницької (Ужвій), М. Тінського, А. Хорошуна, Г. Пелешенка, О. Осташевського, В. Мусієнка, Є. Хуторної, К. Осмяловської, І. Ковалевського, К. Мельник (Загорянської) та інших. Якщо ескізи сценографії та костюмів виконано здебільшого графітним олівцем, то при створенні образів акторів художник звертався до виражальних можливостей кольору: олівцеву лінію доповнено площинною заливкою гуаші (рожевої, пурпурової, зеленої, тілесної), акценти зроблено чорною гуашшю та білилами. Невідомський не обмежується зображеннями облич, подаючи повнофігурні портретні образи у різноманітних позах та рухах: В. Мусієнка (с. 43) зображено сидячим на підлозі, підібгавши під себе одну ногу й виставивши другу, а Н. Ужвій (c. 42) - в русі зі спини тощо. М. Невідомський трактує постаті узагальнено, зводячи їх до геометризованих структур.

Привертають увагу зображення варіантів акторського гриму під назвою «Криве люстро» (с. 60, 61 та 62): викривлені маски-обличчя у різних поворотах, виконані однією виразною, впевненою лінією. Невідомський досяг особливої виразності, використавши мистецький 
прийом А. Дюрера, - не спотворюючи риси хаотично, а варіюючи лише одну з основних пропорцій [3, с. 226].

Зарисовки акторів в ролях персонажів вистави «Палії» («Полум’ярі») 3 робочого зошиту М. Невідомського, дають підстави для атрибутації досі не визначеного імені художника цієї постановки, здійсненої на сцені театру імені Т.Шевченка під час гастролей у Полтаві у 1924 році [2, с. 326]. Згідно досліджень, п’єса «Палії» («Полум'ярі») мала, окрім полтавської, декілька інсценізацій: вперше була поставлена режисером Б. Глаголіним на сцені театру імені І. Франка у Харкові у 1924 році, сценографію до якої створював М. Драк [2, с. 190], а у 1925 році вистава була представлена в Одеському драматичному театрі зі сценографією М. Матковича [2, с. 192]. Зважаючи на досліджені начерки, на яких вказані прізвища артистів-шевченківців - Н. Ужвій у ролі Діани [10, с. 27] (у Харкові ії зіграла В. Варецька) [4, с. 248], М. Тінського у ролі Руделіко (в Одесі його грав К. Блакитний) [4, с. 252], О. Осташевського у ролі Рагіна, І. Ковалевського у ролі Барона, Г. Пелешенка у ролі Поляка, А. Хорошуна у ролі Магометова - можна з впевненістю стверджувати, що художником цієї вистави був саме Микола Невідомський.

Досліджені робочі начерки, зарисовки та ескізи Миколи Невідомського розкривають творчу постать художника як значного театрального художника першої половини XX століття і спонукають до подальшого вивчення його творчого спадку.

\section{Література:}

1. Богомазов О. Живопис та елементи. [Б. м.] : Задумливий страус, 1996. $206 \mathrm{c}$.

2. Веселовська Г. Театральний авангард. Київ : Фенікс, 2010. 368 с.

3. Дюрер А. Дневники, письма, трактаты. Том 2. Ленинград Москва : Искусство, 1957. 253 с.

4. Срмакова Н., Нятко П. А. Луначарський «Полум'ярі». Український театр XX століття: Антологія вистав. Київ : Фенікс, 2012. C. $244-254$.

5. Історія українського кіно. Т. 2. 1930-1945. Київ : ІМФЕ, 2016. $448 \mathrm{c}$.

6. Мельниченко В. Шевченкіана Черкащини. Черкаси : БрамаУкраїна, 2013. 208 c.

7. Мих. і Мик. Рік роботи театру «Червоний перець». Сільський театр. 1929. № 11. С. 28-29.

8. Театрально-декораційне мистецтво. Енциклопедія українознавства: Словникова частина / Ред. В. Кубійович; Наукове 
товариство ім. Т. Шевченка у Львові. Т. 8: Париж - Нью-Йорк : Молоде життя, 1976. Репринтне відтворення: Львів, 2000. С. 3155-3157.

9. Український драматичний театр. Нариси історії в 2-х томах. Т. 2. Київ : Видавництво Академії наук Української РСР, 1959. 646 с.

10. Шпаковська Т. Дніпровський академічний музично-драматичний театр імені Т. Г. Шевченка. Київ: Логос Україна, 2018. 245 с.

11. Центральний державний архів-музей літератури i мистецтв України. Путівник. Вип. 1. Київ, 2003. 553 с.

DOI https://doi.org/10.30525/978-9934-26-004-9-51

\title{
АНАТОМІЧНІ РИСУНКИ К. К. КОСТАНДІ 3 ФОНДІВ НАЦІОНАЛЬНОГО ХУДОЖНЬОГО МУЗЕЮ УКРАЇНИ
}

\author{
Мельничук А. I. \\ аспірантка кафедри теорії і історії \\ Національної академії образотворчого мистецттва і архітектури \\ м. Київ, Україна
}

Український художник Киріак Костянтинович Костанді початкову художню освіту здобув у фотографа Булова, а в 70-х роках XIX ст. відвідував класи рисувальної школи Товариства красних мистецтв [3, с. 28]. У 1874 році Костанді вступає до Імператорської академії мистецтв у якості вільного слухача (оскільки не мав атестату про середню освіту). I лише у 1877 році стає студентом Академії мистецтв, де його наставниками були А. Куїнджі, I. Рєпін, І. Крамський, а також П. Чистяков, якого художник згадує з великою повагою та вдячністю. Зі слів сина художника, в академії К.К.Костанді за порадою П. Чистякова, робив багато копій $з$ творів старих майстрів (особливо В. Тіціана та П. Рубенса) в Ермітажі [2, с. 11]. Як зазначав сам Чистяков - «справжня техніка в мистецтві доступна лише художникам, що вивчають анатомію та перспективу, дві необхідні науки, що допомагають піднятись до високого мистецтва».

Принцип наукової обізнаності має важливе значення в академічній системі XIX ст., в час становлення російського реалізму, який дає підвалини до створення методичної бази для художньої освіти. 3 метою підвищення освітнього рівня та художньої майстерності майбутніх митців, 